\title{
Radical Approaches During Unusual Circumstances: Intellectual Property Regulation and the COVID-19 Dilemma
}

\author{
Mohammed El Said ${ }^{1}$
}

Published online: 6 November 2020

(c) Society for International Development 2020

\begin{abstract}
The current outbreak of COVID-19 pandemic traces its roots back many decades and is worsened by a number of ill-conceived strategies and policies. The current patent protection regime and its suitability in dealing with the current COVID-19 pandemic need to be questioned. Strengthened intellectual property protection manifested by the rise of TRIPS-Plus standards is having a negative impact on the affordability and accessibility of medicines. Dealing with the current pandemic urgently demands serious reform and collective efforts.
\end{abstract}

Keywords IP Protection · TRIPS-Plus · FTAs · TRIPS flexibilities · COVID-19 · Access to Medicines

2020 has been an eventful year for what we know. Marked by the so far unstoppable outbreak of the Coronavirus (COVID19) pandemic, the year will also be remembered for the newly adopted wealth of vocabulary. 'Social and physical distancing', 'shielding', 'testing', 'vaccine wars', 'self-isolating', 'pandemic', 'quarantine', 'lockdowns and curfews', 'covidiots', 'herd immunity' and 'key workers' are few examples. Although the usage of these expressions within the current circumstances is new, no one can claim that the threat of a serious disease developing into a pandemic was not envisioned, even in the recent past. In fact, what is rather interesting is that this has not taken place much earlier, considering that the last global pandemic which humankind had to face took place over a hundred years ago (the 1918 influenza pandemic known as the Spanish flu) and noting that during the past few decades we have had to deal with the outbreak of a number of troubling diseases such as Ebola, SARS-CoV and H1N1 which all had the potential to become pandemics as well.

Looking at the current situation from this perspective, the question which often arises is how did we get to this stage in today's world despite all the progress made in so many fields specially in terms of innovation, development, medical and technological health advances? Did we simply ignore

Mohammed El Said

mel-said@uclan.ac.uk

1 University of Central Lancashire, Preston, UK the signs or, to the contrary, adopted policies and strategies which exacerbated this situation throughout the years?

This article will argue that the policies advocated and adopted by many during the past decades have curtailed our ability to deal with the current situation efficiently. Higher levels of intellectual property rights (IPRs), lack of innovation and R\&D for treatment in certain diseases and technologies, and our inability to learn from previous experiences have made the current situation extremely difficult and potentially untenable at least in the short term. These factors have led to higher prices of medicines and lack of affordability and accessibility to treatment hence making a larger segment of society more susceptible to the current virus, and as a result placing additional constraints on governments and individuals alike. In addition, it is acknowledged that the farreaching measures taken to combat the pandemic will have a massive impact on human rights and the implementation of the internationally agreed Sustainable Development Goals (SDGs). ${ }^{1}$ As such, radical thinking is needed in order to deal with these unprecedented circumstances before it is too late.

\footnotetext{
${ }^{1}$ Spotlight on Sustainable Development 2020. CESR. Global Civil Society Report on the 2030 Agenda and the SDGs. https://www.cesr. org/spotlight-sustainable-development-2020. Accessed September 18, 2020.
} 


\section{Higher Prices of Medicines}

The price of medicines has been on a steady increase for some time. In the US, prices for branded prescription drugs doubled in 5 years between the period of 2011-2016. ${ }^{2}$ Further, it was projected that the prices of medicines in the US will increase on average $5.8 \%$ in $2020 .{ }^{3}$ A recent study in the UK found that total National Health Service (NHS) spending on medicines in England has grown from GB£13 billion in 2010/11 to GB£17.4 billion in 2016/17—an average growth of around 5\% a year (Ewbank et al. 2018).

Medicines costing millions of dollars in not unheard news in today's world. In March 2019, the United States Food and Drug Administration (USFDA) approved the most expensive medicine in history called Zolgensma (priced at US\$2.125 million), a medicine used for a rare disorder that destroys a baby's muscle control and kills nearly all of those with the most common type of the disease within a couple of years. Newly developed hepatitis C drugs' prices have also been set out of the reach of the majority in both low-income and high-income countries. ${ }^{4}$

The effects of this scenario are being felt globally. Greater number of patients are now unable to afford medicines while governmental health budgets are struggling to cater for the needs of their citizens. Even worse within the context of the current pandemic, it is established that those who have a serious premedical condition are more vulnerable. A recent study by the Lancet found that one in five people worldwide are vulnerable to severe COVID-19 due to chronic health conditions (Clark et al. 2020). As such, the current accessibility to medicines dilemma coupled with the ongoing global crises can only deepen these wounds further unless speedy and logical solutions are implemented.

\footnotetext{
${ }^{2}$ Lives on the Edge: Time to Align Medical Research and Development with People's Health Needs. Médecins Sans Frontières Access Campaign. https://msfaccess.org/lives-edge-time-align-medical-resea rch-and-development-peoples-health-needs. Accessed 11 September 2020.

${ }^{3}$ In 2019 it was reported that more than 50 companies raised the prices on hundreds of drugs in the US by an average of more than $6 \%$ (Hopkins 2020).

${ }^{4}$ It's been reported that Sovaldi a hepatitis C drug was introduced at a list price of US\$ 84,000 for a standard twelve-week treatment course, or about US\$ 1000 a pill. At the most recent average net price of US\$ 45,000 per patient for all sofosbuvir-based products in the US, it would cost US\$135 billion dollars to treat the estimated three million people with chronic hepatitis $\mathrm{C}$ in the US-over one-third of total annual spending on all prescription drugs in the US. "America's Overspend: How the Pharmaceutical Patent Problem is Fuelling High Drug Prices' I-MAK. http://www.i-mak.org/wp-content/uploa ds/2017/10/Excess-Costs-Briefing-Paper-FINAL_-2017-10-24.pdf. Accessed 11 September 2020.
}

\section{Now and Then: Lessons from History for the Future}

Governments are under extreme pressure to manage the current situation and its ramifications at both the domestic and international levels. ${ }^{5}$ Demonstrations and protests are taking place regularly in several European and US cities channelling different lines of collective concerns. Some are directed towards governments' inability to control the diseases and save the lives of many, while others give voice to the growing anger about the extreme measures taken to deal with and control the spread of the disease. ${ }^{6}$ Meanwhile, many protests in the US are taking place as part of the Black Lives Matter movement, revealing the need for a systemic review of institutional violence and discrimination (Buchanan et al. 2020).

As the wait for a vaccine or effective treatment of COVID-19 continues, attempts are made in order to reassure the population that all necessary measures are taken by stockpiling and pre-ordering of vaccines, despite the fact that previous experiences have shown the inadequacy of this approach and its culmination in the wasting of huge amounts of public resources. ${ }^{7}$ For instance, in August 2020, it was announced that the United Kingdom would secure 90 million doses of two promising COVID-19 vaccine candidates, joining a growing group of rich countries. This resembles the previously failed attempt in dealing in the case of H1N1 back in 2002, whereby government agencies in the EU and US (in addition to WHO's initial supportive stance at the time) recommended the use of Oseltamivir (Tamiflu), a

\footnotetext{
5 The WTO estimates that 'global air cargo capacity shrank by 24.6 per cent in March 2020, as passenger flights account for around half of air cargo volumes. The resulting increase in air freight prices is likely to subside only with a rebound in passenger transport, according to the report. 'TRADE COSTS IN THE TIME OF GLOBAL PANDEMIC KEY POINTS'. WTO, 12 August 2020. Accessed 11 September 2020. https://www.tralac.org/documents/resources/covid -19/4008-trade-costs-in-the-time-of-global-pandemic-wto-informatio n-note-august-2020.html. Furthermore, according to IMF forecasts, world production (GDP) may decline by $3 \%$ on average (up to $7.5 \%$ as to the eurozone) in 2020 with scant perspective that any 2021 recovery may fill the loss. 'World Economic Outlook Database April 2020'. International Monetary Fund. https://www.imf.org/external/ pubs/ft/weo/2020/01/weodata/index.aspx. Accessed 11 September 2020.

${ }^{6}$ Germany Coronavirus: Hundreds Arrested in German 'anti-corona' Protests. BBC News. 30 August 2020. https://www.bbc.com/news/ world-europe-53959552. Accessed 11 September 2020.

7 Some existing medicines that have been beneficial in some cases are being repurposed for the treatment of COVID-19. Several of these drugs are part of a Solidarity Trial by the World Health Organization (WHO). "'Solidarity" Clinical Trial for COVID-19 Treatments'. World Health Organization. https://www.who.int/emergencie s/diseases/novel-coronavirus-2019/global-research-on-novel-coron avirus-2019-ncov/solidarity-clinical-trial-for-covid-19-treatments. Accessed 11 September 2020.
} 
neuraminidase inhibitor, ${ }^{8}$ for treatment and prophylaxis of influenza, and its stockpiling as a measure to tide over the crisis that time, despite the fact that no scientifically robust data on efficacy and safety of the drug was available. Even worse, serious adverse cases, especially neuropsychiatric events associated with Tamiflu, started getting reported leading to a cascade of questions on the clinical utility of this particular drug (Gupta et al. 2015).

Finally, in 2014, the Cochrane Review findings concluded that there were small benefits on symptom relief, namely shortening duration of symptoms by half a day on average. In general, however, there is little evidence to support any belief that use of neuraminidase inhibitors (NIs) such as Tamiflu reduces hospital admission or the risk of developing confirmed pneumonia. The evidence also suggests that there are insufficient grounds to support the use of NIs in preventing the person-to-person spread of influenza (Jefferson et al. 2014).

Unfortunately, as highlighted, it appears that some governments are repeating the same scenario which may further result in more 'costly mistakes' at a time where resources are stretched further. More worryingly, health experts and access advocates warn that this approach may in fact leave 'poorer countries in the lurch as states scramble to pre-order doses while COVID-19 vaccine candidates enter late stage clinical trials' (Ren 2020). Access to medicines advocates decried the move, accusing the UK of fuelling 'vaccine nationalism' and joining other rich countries to 'hoard' the vaccine before it even hits the market (Ren 2020).

Unfortunately, a similar scenario is also taking place with remdesivir- an antiviral that was shown to reduce hospitalization times for COVID-19 patients-, one of the few promising treatments currently used in the fight against COVID-19. In early July 2020, it was announced that the US had secured almost all of Gilead Sciences' projected production of remdesivir for the next three months. The US Health and Human Services (HHS) stated in a press release that it secured $100 \%$ of Gilead's projected production for July (94,200 treatment courses), $90 \%$ of production in August (174,900 treatment courses), and 90\% of production in September $(232,800$ treatment courses), in addition to an allocation for clinical trials. ${ }^{9}$ Although the motives of the US administration behind such a decision are clear, the moral and ethical questions which are raised in this regard are also very evident. How are other countries supposed to access

\footnotetext{
8 This was approved for seasonal flu by US Food and Drug Administration in 1999.

9 U.S. Department of Health and Human Services. 'Trump Administration Secures New Supplies of Remdesivir for the United States'. HHS.gov. 29 June 2020. https://www.hhs.gov/about/ news/2020/06/29/trump-administration-secures-new-supplies-remde sivir-united-states.html. Accessed 11 September 2020.
}

remdesivir, particularly in the absence of the availability of the treatment and in the situation of lack of licensing by the rightsholders? As Maybarduk explains, 'The countries that are not covered by Gilead's license would have to buy from Gilead, but they can't buy from Gilead because the United States and Europe have bought up the entirety of Gilead's supply,' (Vijay 2020) Gilead will have only 15,300 treatment courses available for countries outside the EU and US to access from August to September (Rizvi 2020).

These examples show how little was learnt from previous experiences. They also reflect a clear lack of understanding about the current priorities. More worryingly and contrary to public understanding, is the fact that governmental regulatory food and drug authorities may not fully get things right all the time as the Cochrane Review demonstrated.

\section{IPRs and the Rise of TRIPS-Plus World}

As often been acknowledged, intellectual property protection has a direct negative impact on the affordability and availability of medicines and medical technologies. Within the current debate, intellectual property is both seen and used as a sword and a shield at the same time.

Historically, developed countries have pushed for the strengthening of IP protection due to their status as net importers of IP-related goods and services (Sell 2003). The aggressive push resulted in the creation of the Agreement on Trade-Related Aspects of Intellectual Property (TRIPS Agreement) in $1995,{ }^{10}$ thus creating for the first time a binding and comprehensive international agreement covering the majority of IP rights. The Agreement dictates that patent protection is awarded to all types of inventions including those related to pharmaceutical patents. Although many policymakers in developed countries were convinced that TRIPS would put an end for the 'ratching up' of IP protection levels globally, the outcome was to the contrary. Within less than a decade from the birth of the TRIPS Agreement, the proliferation of free trade (FTAs) and bilateral investment (BITs) agreements containing heavy IP obligations which go beyond those prescribed under the TRIPS Agreement became the norm. These agreements setting higher levels of IP protection are commonly referred to as 'TRIPSPlus' agreements (El Said 2005).

In simple terms, TRIPS-Plus rules restrict countries' freedom and ability to utilise available policy space and direction when designing and implementing their national

\footnotetext{
10 The Agreement on Trade-Related Aspects of Intellectual Property Rights, 15 April 1994, Marrakesh Agreement Establishing the World Trade Organization, Annex 1C, 1869 U.N.T.S. 299, 33 I.L.M. 1197 (1994) [hereinafter TRIPS Agreement].
} 
IP protection regime by incorporating extensive protection levels which go beyond those incorporated under the TRIPS Agreement. This approach is championed by the EU and US and has taken an 'upward' trend over the time, whereby more and more obligations were added to each subsequent agreement signed.

In order to understand how TRIPS-Plus conditions erode policy space within the patent regime, an explanation of the meaning of TRIPS flexibilities (and their advantageous utilization) would be helpful in this context. As such, the TRIPS Agreement adopts a 'minimum standards' of protection approach, which means that all WTO member states will have to provide the minimum ceilings of protection as prescribed under the TRIPS Agreement under their national laws, while at the same time are free to raise the levels above those if they deemed so in accordance with their national priorities and development stages and subject to respecting the Most Favoured Nation (MFN) and National Treatment (NT) principles. This approach provided member states with a reasonable policy space and flexibility in some respect about how to incorporate and define the 'minimum standards' under their national legislations and legal regimes. The following are some examples of these flexibilities with selected examples about the positive impact their use had on the accessibility and affordability of medicines.

- Transition periods Least developed countries (LDCs) were granted an extended transition period exempting them from protecting intellectual property as stated under the WTO's TRIPS Agreement. This is in recognition of their special developmental needs and the balance that should be put in place prior to the introduction of intellectual property protection under their national law. More recently, several extensions of the transition period were provided by the TRIPS Council. ${ }^{11}$ This means LDCs can choose not to provide legal protection for pharmaceutical patents and clinical trial data before 2033. The decision also keeps open the option for further extensions beyond that date. ${ }^{12}$ A number of low-income countries-Uganda, Cambodia and Rwanda for example- have already ben-

\footnotetext{
11 The last 6 November 2016 Council decision extends until January 2033 the period during which key provisions of the WTO's intellectual property agreement, the TRIPS Agreement, do not apply to pharmaceutical products in LDCs. See the Council for Trade-Related Aspects of Intellectual Property Rights, Extension of the Transition Period under Article 66.1 of the TRIPS Agreement for Least Developed Country Members for Certain Obligations with Respect to Pharmaceutical Products, Decision of the Council for TRIPS of 6 November 2015 .

12 In 2019, Uganda notified the African Regional Intellectual Property Organization (ARIPO) that it is exercising its right as a leastdeveloped country by stating that pharmaceutical inventions are not eligible for patent protection in the country ("t Hoen 2019).
}

efited from this flexibility hence ended up using the full transition period granted to them.

- Compulsory licensing It allows the state to authorize a third party to exploit patented inventions, generally against a specific remuneration to be paid to the patent holder subject to meeting several conditions (Article 31 of the TRIPS Agreement). The aim of compulsory licensing authorization is to limit anti-competitive behaviour and facilitate the transfer of technology. ${ }^{13}$ This tool has proven its effectiveness in a number of cases in terms of dealing with national health priorities by reducing prices of medicines substantially where a national production capability exist. For instance, the Ecuadorian Institute of Intellectual Property (IEPI) reported that between 2013 to 2017 it issued ten compulsory licences for various medications including antiretroviral drugs. ${ }^{14}$ According to health officials in Ecuador, the compulsory licenses granted between 2013 and 2014, generated the potential for savings of 23\% to 99\% (Correa and Velásquez 2019). Similar reductions were also achieved in the case of other compulsory licenses issued by Thailand, India, Indonesia, Brazil and Columbia (El Said 2016). Despite this, it should be noted that the process of issuing a compulsory license is often marred by bureaucratic requirements and political pressure exerted against those countries issuing such licenses (Ooms and Hanefeld 2019).

- Government use exceptions This flexibility gives the state the right to use the patent without the need to acquire the approval of the patent holder for the purpose of public interest, including public health necessities and emergencies. Although there are similarities between the conditions needed to issue a government use and compulsory licensing, government use exceptions provide an additional advantage by allowing the license to be issued in a speedy manner, through granting the government the right to use the pharmaceutical patent without the need for prior negotiations with the owner. Positive examples of using this flexibility are many. For instance, in 2017 Malaysia issued a 'government use' compulsory license to obtain a cheaper generic version of the widely known

\footnotetext{
13 The special compulsory licensing system in the amended TRIPS Agreement, and the earlier 2003 waiver decision, (sometimes called the 'Paragraph 6 System' because it refers to paragraph 6 of the Doha Declaration) only deals with compulsory licences to produce medicines expressly for export purposes.

${ }^{14}$ The issued compulsory license were for three ARV medicines namely Ritonavir + Lopinavir and Lamivudine + Abacavir, for Etoricoxib (Arcoxia ${ }^{\circledR}$ for the treatment of diseases with acute pains); Mycophenolate Sodium (MYFORTIC) used in the treatment of reception of kidney transplants; sunitinib, an anticancer drug used for the treatment of carcinoma renal cells (CRC) and gastrointestinal stromal tumours (GISTs); and finally Certolizumab, used to counter-
} act rheumatoid arthritis. 
hepatitis $\mathrm{C}$ medicine Sofosbuvir. It is believed that this compulsory license has enabled a cheaper treatment cost to be between RM 1000 to RM 1200 (US\$ 240-US\$ 285) for 12 weeks course, compared to RM 300,000 (approx. US\$ 72,000) which was the cost of treatment with the patented version prior to issuance of the license (Ling 2019).

- Parallel importation This flexibility grants countries the option to obtain patented products when they are lawfully available in a foreign market at a lower price, thus enabling countries to shop for cheaper patented products. ${ }^{15}$ For example, Kenya has actively and effectively used parallel importation to improve access to antiretroviral medications. ${ }^{16}$

- Exceptions to patents rights Article 30 of TRIPS provides that members 'may provide limited exceptions to the exclusive rights conferred by a patent, provided that such exceptions do not unreasonably conflict with a normal exploitation of the patent and do not unreasonably prejudice the legitimate interests of the patent owner, taking account of the legitimate interests of third parties'. ${ }^{17}$ However, the above provision does not define the scope of the permissible exceptions thus awarding member countries some considerable discretion to operate. Examples of these exceptions include the Bolar exception, ${ }^{18}$ personal use and the research and experimental use exceptions.

- Standards of patentability Under TRIPS, patent protection must be granted for products and processes which are new, involve an inventive step and are industrially applicable. ${ }^{19}$ These are not defined and can be interpreted and applied by member states in accordance with their national legal regimes. For example, TRIPS does not require countries to protect the patenting of new uses of known products, including pharmaceutical drugs. This flexibility therefore allows member countries the pos-

\footnotetext{
$\overline{15}$ See TRIPS Agreement, Article 6.

16 'DOHA +10 TRIPS FLEXIBILITIES AND ACCESS TO ANTIRETROVIRAL THERAPY: LESSONS FROM THE PAST, OPPORTUNITIES FOR THE FUTURE', UNAIDS, " https:// www.hst.org.za/publications/NonHST\%20Publications/JC2260_ DOHA+10TRIPS_en.pdf. Accessed 11 September 2020.

17 TRIPS Agreement, Art. 30.

18 This important exception facilitates the production and introduction of generic medicines into the market on the date of patent expiry. Accordingly, this exception permits the use of an invention for the purpose of obtaining approval of a generic product before the patent actually expires and without having to obtain the patentee's approval. The WTO ruled that the use of this exception is TRIPS-compliant. For more see the WTO, 'Canada-patent protection of pharmaceutical products' (2000) Geneva, WTO Dispute Panel Report, WT/ DS114/1.

19 TRIPS Agreement, Art. 27.
}

sibility of rejecting the patentability of these new uses for lack of novelty, inventive step or industrial applicability. The case of India provides some valuable insights regarding this approach whereby strict patentability criteria aimed towards limiting the number of frivolous or secondary pharmaceutical patents granted are applied (Chatterjee 2013). This has the effect of limiting patent abuse cases by not granting of low-quality patents (antievergreening strategy). ${ }^{20}$ Egypt is also applying similar vigorous examination practises. The country is home to the highest rate of hepatitis $\mathrm{C}$ infections in the world. A couple of years ago the Egyptian's Patent Office rejected one of Sofosbuvir patent applications through resorting to strict patentability criteria. This allowed a local generic manufacturer to produce the drug for less than US\$ 200 per twelve-week treatment.

- Other procedural flexibilities Another identified policy tool used by low-income and high-income countries to improve the quality of granted patents and limits 'evergreening' is pre-grant and post-grant patent oppositions, in addition to patent revocation proceedings. Such proceedings enable interested parties to bring claims before the patent office on the basis that a particular patent does not meet local requirements. Opposition procedures have been applied usefully and efficiently in several countries. ${ }^{21}$ This is an important procedure due to the fact that it is believed that current estimates suggest that at least $27 \%$ of current patents would be found invalid by US courts due to low quality (Miller 2012).

As highlighted earlier, recent FTAs containing TRIPSPlus standards of protection have targeted precisely the above examined flexibilities during the past two decades resulting in the erosion of policy space and diminishing of flexibilities usage in many countries. ${ }^{22}$ As such, the following are some examples of these TRIPS-Plus standards supported by some selected examples about their negative impact on access to medicines.

Expanding and extending the scope of pharmaceutical patents and creating new drug monopolies: this is achieved through lowering the patentability standards and allowing

\footnotetext{
${ }^{20}$ Other countries are increasingly following India's patentability path. The Philippines patent law, as amended in 2008, introduced a section similar to the Indian 3(d) section (although less stringent than India's Patent Act).177. China has reformed its Patent Act in 2008 and 178. See Patent Law (promulgated by the Standing Comm. Nat'l People's Cong., Mar. 12, 1984, rev'd Dec. 27, 2008), art. 22.

${ }^{21}$ WIPO, Opposition Systems, Document prepared by the Secretariat, Geneva, SCP/17/9, 31 October 2011. https://www.wipo.int/edocs/ mdocs/scp/en/scp_17/scp_17_9.pdf. Accessed 1 October 2020.

${ }^{22}$ Examples of these include the US-Jordan FTA, the US-Singapore FTA, the US-Korea FTA and the Trans-Pacific Partnership Agreement (TPPA)
} 
for new and second use patenting in addition to vaccines and gene patenting and prolonging the patent protection term. A study by Amin and Keselheim on the impact of 'evergreening' resulting from the granting of secondary patents concluded that secondary patents could extend market exclusivity for many years. The study identified 108 patents related to two HIV medicines (ritonavir (Norvir) and lopinavir/ritonavir (Kaletra)) whose impact could delay generic competition until at least 2028. This is a twelve years additional period after the expiration of the patents on the drugs' base compounds and thirty-nine years after the first patents on ritonavir were filed (Amin and Kesselheim 2012: 2286).

- Protection and Extension of 'data exclusivity' and patent linkage: by requiring protection of at least 5 years exclusivity for information related to new products and 3 more in cases of new uses for old medicines-even when that information is disclosed and available in the public domain. ${ }^{23}$ Another TRIPS-Plus requirement is the linking of the status of patent grant with marketing approval. A 2007 Oxfam study on the effect of the US-Jordan FTA found that since 2001 the prices of medicines in Jordan have increased by $20 \%$ (this led to price soaring between two and ten-fold for key medicines to treat cardiovascular disease and cancer), and data protection provisions have resulted in delaying generic drugs entry for $79 \%$ of medicines newly launched between the years 2002 and 2006 (Oxfam 2007).

- Prohibition/restriction pre-grant oppositions: These restrictions forbid challenges to weak or invalid patents until after they have been granted. As highlighted above this is a real dilemma is we take into consideration the estimates suggesting that at least $27 \%$ of current patents would be found invalid by US courts due to their low quality (Miller 2012: 28).

- Requiring new forms of intellectual property enforcement These requests include claims related to customs detaining shipments, including in-transit shipments, suspected of non-criminal trademark/copyright/patent infringements; require mandatory injunctions for alleged intellectual property infringements; raise damages amounts... etc.

Introducing Investor-State Dispute Settlement (ISDS) procedures This highly controversial aspect of the FTAs and

\footnotetext{
23 More recent FTAs have also provided 10 years of 'effective market protection' for biologics. 'Exclusivity for Biologic Products Under the USMCA: What Is Changing, and What Happens Next?', The Center For Biosimilars. 2019. https://www.centerforbiosimilars.com/ contributor/joshua-ney/2019/08/exclusivity-for-biologic-productsunder-the-usmca-what-is-changing-and-what-happens-next. Accessed 11 September 2020 .
}

BITs grants private investors, especially big multinational corporations, considerable power to claim huge amounts compensation from investor sympathetic tribunals in case where governments take certain measures which may be considered from the perspective of an investor as expropriation, discriminatory or breaches other general substantive standards or protection in that state. This question the impact of these claims on states' power to regulate in the public interest, in order to safeguard public health priorities and challenges. An example of this controversial aspect was demonstrated in the Philip Morris Asia versus Australia ${ }^{24}$ case whereby the Australian Federal Government passed the Tobacco Plain Packaging (TPP) Act in 2011 requiring restrictions on the use of advertisements of tobacco and the increase of the size of the graphic health warnings on the front face of the pack from 30 to $75 \%$ based on public health considerations. This decision was challenged by the tobacco industry alleging that the measures amounts to expropriation and interferes with their trademarks rights in Australia and breaches international IP- investment- and trade law under the bilateral investment treaty (BIT) between Hong Kong and Australia (HK-AUS BIT). They unsuccessfully demanded the suspension of the measures and compensation amounting to billions of dollars ${ }^{25}$ Other flaws of the ISDS system include the lack of consistency in decision making and huge costs. There is now growing evidence that the threat of using these ISDS procedure is enough to obligate countries to change their policies. ${ }^{26}$

The effect of these TRIPS-Plus standards has been acknowledged by many in recent times resulting in even higher medicines prices and longer monopoly term all at the expense of patients and citizens particularly in low-income countries. (El Said, 2010). This issue should not be seen in isolation of the current crises facing many across the globe. This is the case specially since those 'vulnerable' segments of society are more susceptible to have severe COVID-19 infections or higher mortality rates. In fact, according to a recent World Bank study it is believed that the share of lowincome countries in global fatalities from COVID-19 could be three times higher than other countries (Schellekens and Sourrouille 2020). As such and since many of those vulnerable patients could not afford basic treatment in many cases

\footnotetext{
${ }^{24}$ Philip Morris Asia Limited v. The Commonwealth of Australia, UNCITRAL, PCA Case No. 2012-12.

${ }^{25}$ Philip Morris Asia Files Lawsuit Against the Australian Government Over Plain Packaging, News Release, Philip Morris International, 21 November 2011. https://www.prnewswire.com/news-relea ses/philip-morris-asia-files-lawsuit-against-the-australian-government -over-plain-packaging-134223218.html.

${ }^{26}$ For instance, in 2016, Ukraine deregistered a generic hepatitis C medicine after Gilead indicated that it would pursue arbitration (Gleeson et al. 2019).
} 
due to high prices and patent monopolies, it is believed that the current outbreak can only drive them more in despair.

\section{IP Protection in the Times of COVID-19}

Many measures have been desperately taken by governments with the aim of containing the spread of the current outbreak, from curfews to lockdowns, social distancing and shielding. Despite the fact that global calls for solidarity have been made by many including the United Nations, the World Health Organization (WHO), the World Bank and the WTO in order to deal with the crisis, ${ }^{27}$ we have also witnessed some resistance by IP holders aimed at protecting their proprietary rights. ${ }^{28}$

In recognition of IP's ability to restrict the accessibility and production of certain medical and diagnostic products and goods, governments have taken several intellectual property-related measures in order to deal with the current situation and overcome the barriers created by the IP regime. ${ }^{29}$

The need to urgently secure essential products including medicines, personal protective equipment, testing kits, CT scanners, and ventilators has been identified as a priority by many countries from the beginning of the pandemic leading some to even ban their exportation (Boykoff 2020). Furthermore, several low-come and high-income countries have already taken concrete steps in order to facilitate access to medications and medical equipment through limiting or removing any intellectual property restrictions in this regard by issuing compulsory licenses and government use authorizations. For instance, on 17 March 2020 the Parliament of Chile adopted Resolution No. 896 declaring that the global coronavirus outbreak justifies the use of compulsory licensing to facilitate access to vaccines, drugs, diagnostics, devices, supplies, and other technologies useful for the surveillance, prevention, detection, diagnosis and treatment of the coronavirus in Chile (Syam 2020: 2-3). Israel took similar measures by issuing a government use authorization under the Israeli patent law for the importation of generic lopinavir/ritonavir (owned by AbbVie) combination for the treatment of COVID-19 patients from an Indian generic company by a local company acting on behalf of the Israeli

\footnotetext{
27 'Intellectual Property Measures - COVID-19: Trade and Traderelated Measures'. WTO. 2020. https://www.wto.org/english/tratop_e/ covid19_e/trade_related_ip_measure_e.htm. Accessed 11 September 2020.

${ }^{28}$ Indeed, it's been reported that there were cases where patent infringement proceedings have been initiated or transfer of technical designs have been denied to third parties manufacturing IP protected products to meet the demand in the context of COVID-19 (Tietze et al. 2020).

${ }^{29}$ For a detailed analysis of measures Syam (2020).
}

ministry of health because AbbVie was unable to provide sufficient supplies of lopinavir/ritonavir (Syam 2020: 3). AbbVie has announced that it will not enforce its patent in light of the current pandemic. ${ }^{30}$

The use of competition law has often been recognized as an important tool in the process of curtailing IP abuse. More recently, the European Commission (EC) launched a preliminary investigation on the abuse of the dominant position in the Dutch market by the Swiss multinational pharmaceutical company Roche, on account of its reported refusal to share the secret formula for producing a buffer solution that is necessary for use in testing kits for COVID-19. This has lead Roche to immediately announce that it will release the recipe for its lysis buffer if Dutch laboratories ask for it (Van Ark and Strop 2020). The EC has also stated that during the pandemic it will continue to closely and actively monitor relevant market developments to detect instances of potential activities that may take advantage of the current situation to breach European Union competition law and policy, by either engaging in anti-competitive agreements or abusing their dominant position. ${ }^{31}$

Moreover, on 23 March 2020, France enacted a new law No. 2020-290 which introduced one (Art. L.3131-15) to the country's public health law allowing the French Prime Minister to order the seizure of all goods and services necessary to fight against sanitary disaster; to temporarily control the prices of products; and to take any measures necessary to make relevant medicines available to patients (Syam 2020: $3)$.

The above are few examples of the measures targeting the intellectual property rights within the current COVID19 context. These national initiatives represent a patent acknowledgement that such rights need to be restricted and limited otherwise the damage to society would be greater than the benefits of protection.

\section{Conclusion}

The current COVID-19 outbreak represents one of the gravest challenges humankind has had to deal with during the last 70 years or so. The politicization of this crisis and

\footnotetext{
30 'Israel Defies AbbVie IP To Import Generic Drugs For COVID19'. Law360. March 19, 2020. https://www.law360.com/artic les/1255079/israel-defies-abbvie-ip-to-import-generic-drugs-forcovid-19. Accessed 11 September 2020.

31 'Communication from the Commission Temporary Framework for assessing antitrust issues related to business cooperation in response to situations of urgency stemming from the current COVID-19 outbreak 2020/C 116 I/02' European Commission 2020. https://ec.europ a.eu/info/sites/info/files/framework_communication_antitrust_issue s_related_to_cooperation_between_competitors_in_covid-19.pdf. Accessed 11 September 2020.
} 
making decisions based on business and political considerations instead of public health concerns is a real threat and can only prolong the suffering of many. ${ }^{32}$ This situation requires unconventional strategies and polices. It demands a serious breakout from the prevailing traditional way of thinking which dictated our approach in dealing with international economic and trading relations since the 1950s. We must start to critically question the existing policies and their failure and proactively seek a new and more inclusive approach in dealing with these trade and health issues. If not now, then when?

The starting point in this debate is the acknowledgment that we have a flawed global patent regime in place in need of a desperate and urgent reform. Of course, it should be made clear that the current regime is not the only reason for our challenges and other factors should also be equally dealt with including inadequate $\mathrm{R} \& \mathrm{D}$ levels, procurement policies, tax reform, judicial reform and so forth. Calls for the need of a reformed patent regime are not new. However, the systemic conflict between strengthened patent protection and public health needs and challenges is rising and this explains why some of the high-income countries are often the first to initiate restrictions and impose limitations on the intellectual property regime during public health crises, such as the one we are currently facing.

There is also an urgent need to put an end to the strengthening of intellectual property protection levels globally. The rise of TRIPS-Plus standards through various agreements and arrangements have had grave repercussions on the needy everywhere and is likely to get worse unless something serious is done about it. A fundamental aspect of this would be to remind ourselves about the public goods nature of health care provision and the need to make decisions departing from this perspective, not business or political considerations. Including TRIPS-Plus standards in new agreements should no longer be allowed, while previously agreed TRIPS-Plus provisions will need to be abolished. Concurrently, governments, health activists and policy makers should start the debate about reforming the TRIPS Agreement and the impact of the patent regime on access to medicines and public health.

The strengthening of the current medical R\&D system is vital as well for both dealing with the current outbreak and other diseases affecting many. The IP regime cannot continue to be used as the main mechanism to compensate innovators but should also be supplemented by other tools. Targeted government funding programmes, prizes schemes,

\footnotetext{
32 'Biopharma Leaders Unite to Stand With Science'. Business Wire. 8 September 2020. https://www.businesswire.com/news/home/20200 908005277/en/Biopharma-Leaders-Unite-Stand-Science. Accessed 11 September 2020.
}

shared pooling arrangements and reward strategies should gain more recognition in this process (Suleman et al. 2020). As importantly, is the need to make available and declare all new vaccines and treatment to COVID-19 as a global public good. Emerging calls such as the one made by Costa Rica in March 2020 for the creation of a global pooling mechanism in order to facilitate access to and use of intellectual property, trade-secret know-how, regulatory data, and other proprietary data for technologies that are useful for the detection, prevention, control, and treatment of the COVID19 pandemic must be given the attention they deserve, if the world is serious about accelerating R\&D. ${ }^{33}$ Finally, transparency in drug pricing is pivotal to ensure that fair compensation is granted to those who invest in finding medical solutions to diseases, and affordable drug prices are applied so that patients can afford them. The 2019 World Health Assembly's resolution supporting greater public disclosure of prices for medicines and other health products is a crucial step in the right direction (Fletcher 2019).

Governments and key international organizations need to promptly capitalize on the current crisis and the opportunities it offers in terms of reforming many of the ill-conceived policies of the past. The solution to today's health emergency is clear; a universal holistic solution whereby all efforts are united and channelled towards finding a vaccine and enhancing treatment to COVID-19 is needed rather a national one. Countries can take whatever national measures available at their disposal including lockdowns, curfews and further travel restrictions...etc. Yet, if this challenge is not dealt with collectively and at a global scale, then COVID19 is likely to stay with us - with all its damaging human, economic, financial and psychological consequences-for a long period of time.

\section{Compliance with Ethical Standards}

Conflict of interest This contribution is free from any conflicts of interest, including all financial and non-financial interests and relationships.

\section{References}

Amin, Tahir, and Aaron S. Kesselheim. 2012. Secondary Patenting Of Branded Pharmaceuticals: A Case Study Of How Patents On Two HIV Drugs Could Be Extended For Decades. Health

\footnotetext{
33 'WHO and Costa Rica Preview Technology Pooling Initiative to Ensure Access to COVID-19 Health Products for All'. World Health Organization. 15 May 2020. https://www.who.int/news-room/detai 1/15-05-2020-who-and-costa-rica-preview-technology-pooling-initi ative-to-ensure-access-to-covid19-health-products-for-all. Accessed 12 September 2020.
} 
Affairs 31 (10): 2286-2294. https://doi.org/10.1377/hltha ff. 2012.0107.

Boykoff, Pamela. 2020. In the Race to Secure Medical Supplies, Countries Ban or Restrict Exports. CNN. 28 March. https:// www.cnn.com/2020/03/27/business/medical-supplies-expor t-ban/index.html. Accessed 11 September 2020.

Buchanan, Larry, Quoctrung Bui, and Jugal K. Patel. 2020. Black Lives Matter May Be the Largest Movement in U.S. History. The New York Times. 3 July. https://www.nytimes.com/inter active/2020/07/03/us/george-floyd-protests-crowd-size.html. Accessed 11 September 2020.

Chatterjee, Patralekha. 2013. Novartis Loses Patent Bid: Lessons From India's 3(d) Experience. Intellectual Property Watch. 4 January. https://www.ip-watch.org/2013/04/01/novartis-loses -patent-bid-lessons-from-indias-3d-experience/. Accessed 11 September 2020.

Clark, Andrew, Mark Jit, Charlotte Warren-Gash, Bruce Guthrie, Harry H.X. Wang, Stewart W Mercer, Colin Sanderson, Martin McKee, Christopher Troeger, Kanyin L Ong, Francesco Checchi, Pablo Perel, Sarah Joseph, Hamish P. Gibbs, Amitava Banerjee, and Rosalind M. Eggo. 2020. Global, regional, and national estimates of the population at increased risk of severe COVID-19 due to underlying health conditions in 2020: a modelling study, Lancet Global Health, June 15. https://www.thela ncet.com/journals/langlo/article/PIIS2214-109X(20)30264-3/ fulltext, at e1003. Accessed 12 September 2020.

Correa, Carlos M., and Germán Velásquez. 2019. Access to Medicines: Experiences with Compulsory Licenses and Government Use-The Case of Hepatitis C. SSRN Electronic Journal. https ://doi.org/10.2139/ssrn.3559640.

El Said, Mohammed K. 2016. TRIPS-Plus, Public Health and Performance-Based Rewards Schemes Options and Supplements for Policy Formation in Developing and Least Developed Countries. Digital Commons @ American University Washington College of Law. https://digitalcommons.wcl.american.edu/auilr /vol31/iss3/2/. Accessed 11 September 2020.

El Said, Mohammed. 2010. Public Health Related TRIPS-PLUS Provisions in Bilateral Trade Agreements, A Policy Guide for Negotiators and Implementers in the WHO Eastern Mediterranean Region, WHO-EMRO. https://applications.emro.who.int/ dsaf/dsa1081.pdf. Accessed 11 September 2020.

El Said, Mohammed. 2005. The Road from Trips-Minus, to Trips, to Trips-Plus. The Journal of World Intellectual Property 8 (1): 53-65. https://doi.org/10.1111/j.1747-1796.2005.tb00237.x.

Ewbank, Leo, Kane Sullivan, Helen McKenna, David Omojomolo. 2018. The Rising Cost of Medicines to the NHS. The King's Fund. 26 April. https://www.kingsfund.org.uk/publications/risin g-cost-medicines-nhs. Accessed 11 September 2020.

Fletcher, Elaine Ruth. 2019. World Health Assembly Approves Milestone Resolution On Price Transparency. Health Policy Watch. 28 May. https://www.healthpolicy-watch.org/world-healt h-assembly-approves-milestone-resolution-on-price-transparen cy/. Accessed 11 September 2020.

Gleeson, Deborah, Joel Lexchin, Ronald Labonté, Belinda Townsend, Marc-André Gagnon, Jillian Kohler, Lisa Forman, and Kenneth C. Shadlen. 2019. Analyzing the Impact of Trade and Investment Agreements on Pharmaceutical Policy: Provisions, Pathways and Potential Impacts. Globalization and Health 15(S1). https://doi.org/10.1186/s12992-019-0518-2.

Gupta, Yogendra Kumar, Meenakshi Meenu, and Prafull Mohan. 2015. The Tamiflu fiasco and lessons learnt. Indian journal of pharmacology 47 (1): 11-16. https://doi.org/10.4103/02537613.150308 .

Hopkins, Jared S. 2020. Drug Prices Rise 5.8\% on Average in 2020. MarketWatch. 2 January 02. https://www.marketwatch.com/ story/drug-prices-rise-58-on-average-in-2020-2020-01-02. Accessed 11 September 2020.

Jefferson, Tom, Mark A. Jones, Peter Doshi, Chris B. Del Mar, Rokuro Hama, Matthew J. Thompson, Elizabeth A. Spencer, Igho J. Onakpoya, Kamal R. Mahtani, David Nunan, Jeremy Howick, and Carl J. Heneghan. 2014. Neuraminidase Inhibitors for Preventing and Treating Influenza in Adults and Children. Cochrane Database of Systematic Reviews. https://doi. org/10.1002/14651858.cd008965.pub4.

Ling, Chee Yoke. 2019.Using compulsory licence for affordable medicines, Astro Awani, http://english.astroawani.com/malay sia-news/using-compulsory-licence-affordable-medicines200558. Accessed 11 September 2020.

Miller, Shawn P. 2012. Where's the Innovation? An Analysis of the Quantity and Qualities of Anticipated and Obvious Patents. SSRN Electronic Journal. https://doi.org/10.2139/ssrn.2029263.

Ooms, Gorik, and Johanna Hanefeld. 2019. Threat of compulsory licences could increase access to essential medicines, 28 May. BMJ 365: 12098. https://doi.org/10.1136/bmj.12098.

Oxfam. 2007. All Costs, No Benefits: How TRIPS-Plus Intellectual Property Rules in the US-Jordan FTA Affect Access to Medicines 7. Oxfam Int'1, Briefing Paper No. 102. https://oxfam ilibrary.openrepository.com/bitstream/handle/10546/114080/ bp102-all-costs-no-benefits-trips-210307-en.pdf\%3Bjsession id\%3D089750820CF675173F0C3204C369D63F\%3Fsequence \%3D1. Accessed 30 September 2020.

Ren, Grace. 2020. Scramble To Preorder COVID-19 Vaccines May Leave Poorer Countries Behind. Health Policy Watch. 14 August. https://healthpolicy-watch.news/scramble-to-preor der-covid-19-vaccines-may-leave-poorer-countries-behind-threa tening-global-response/. Accessed 11 September 2020.

Rizvi, Zain. 2020. Gilead First: How a Monopoly on Remdesivir Led to Rationing. Public Citizen. 2 September 2020. https://www. citizen.org/article/gilead-first/. Accessed 11 September 2020.

Schellekens, Philip, and Diego Sourrouille. 2020. COVID-19 Mortality in Rich and Poor Countries. Open Knowledge Repository. 1 May. https://openknowledge.worldbank.org/handle/10986 /33844. Accessed 11 September 2020.

Sell, Susan K. 2003. Private Power, Public Law: The Globalization of Intellectual Property Rights. Cambridge: Cambridge University Press.

Suleman, Fatima, Marcus Low, Suerie Moon, and Steven G. Morgan. 2020. New Business Models for Research and Development with Affordability Requirements Are Needed to Achieve Fair Pricing of Medicines. BMJ. https://doi.org/10.1136/bmj.14408.

Syam, Nirmalya. 2020. Intellectual Property, Innovation and Access to Health Products for COVID-19: A Review of Measures Taken by Different Countries, Policy Brief 80, June. The South Centre. https://www.southcentre.int/policy-brief-80-june-2020/. Accessed 11 September 2020.

'T Hoen, Ellen. 2019. Uganda tells ARIPO: No more patents for pharmaceuticals. Medicines Law Policy. 8 October. https:// medicineslawandpolicy.org/2019/10/uganda-tells-aripo-nomore-patents-for-pharmaceuticals/. Accessed 11 September 2020.

Tietze, Frank, Pratheeba Vimalnath, Leonidas Aristodemou, and Jenny Molloy. 2020. Crisis Critical Intellectual Property: Findings from the COVID-19 Pandemic, Centre for Technology Management Working Paper Series No.2. University of Cambridge. http://doi.org/10.17863/CAM.51142.

Van Ark, Eelke and Jan-Hein Strop. 2020. Roche Releases Recipe after European Commission Considers Intervention Due to Lack of Coronavirus Tests. Follow the Money-Platform Voor Onderzoeksjournalistiek. 27 March 27. https://www.ftm.nl/artik elen/roche-releases-recipe-after-public-pressure-while-europ 
ean-commission-considers-intervention-due-to-coronaviru s-test. Accessed 12 September 2020.

Vijay, Svĕt Lustig. 2020. Gilead Says Remdesivir Shortages Due To Supply Chain Issues, Civil Society Argues For Wider Licensing. Health Policy Watch. 3 September. https://healthpolicy-watch .news/gilead-says-remdesivir-shortages-due-to-supply-chain -issues-civil-society-argues-for-wider-licensing/. Accessed 11 September 2020.
Publisher's Note Springer Nature remains neutral with regard to jurisdictional claims in published maps and institutional affiliations. 